\title{
La interrelación de las artes en la construcción del discurso autoficcional
}

Fecha de recepción: 22/11/2018. Fecha de aceptación: 27/02/2019.

\section{Resumen}

La producción del artista multiplataforma Benito Laren se caracteriza por la interrelación de sus obras visuales y performáticas con un complejo entramado textual y paratextual. En una suerte de recíproca función disdascálica, las diferentes disciplinas, estéticas y lenguajes operan así en paridad de condiciones en la producción de sentido, no sólo de cada una de las obras individuales y de la lógica interna que las vincula, sino también -y fundamentalmente- de la particular autoinvención ficcional del propio creador.

Palabras clave Laren autoperformance autoficción artes visuales didascalias

\section{The Interrelation of the Arts in the Construction of Autofictional Discourse}

\begin{abstract}
The production of the multiplatform artist Benito Laren is characterized by the interrelation of his visual and performative works with a complex textual and paratextual framework. Acting, in some way, as reciprocal stage directions, the different disciplines, aesthetics and languages thus operate in parity of conditions in the production of meaning, not only concerning each individual work and the internal logic that connects them, but also -and fundamentally- concerning the particular fictional selfinvention of the creator himself.
\end{abstract}

La producción artística y la peculiar autoinvención del realizador multiplataforma Benito Laren conforman un exuberante y complejo entramado de disciplinas, lenguajes, materiales, soportes y géneros diversos, cuya mutua dependencia y complementariedad, articulada a partir de la función didascálica y de la construcción autoficcional, le permite al artista reflexionar sobre cuestiones esenciales que conciernen a diferentes instancias del arte actual.

Keywords Laren Autoperformance Autofiction Visual Arts Stage Directions 
Nacido en 1962, en San Nicolás de los Arroyos, con otro nombre y otro apellido que no suele revelar, el artista que nos ocupa comenzó a firmar sus primeros dibujos a los dieciséis años como Benito, nombre que le daban sus compañeros de escuela, quienes lo veían muy parecido al también nicoleño Benito Urteaga, uno de los comandantes del ERP. Hacia mediados de los 80, coincidiendo con el comienzo de su actividad literaria, Benito completó el seudónimo con el apellido Laren, para parecerse y, al mismo tiempo, diferenciarse de su admirada Sofía Loren. A comienzos de la década siguiente, en tiempos de su participación en las exposiciones del Centro Cultural Ricardo Rojas de la Universidad de Buenos Aires, con un por demás evidente guiño de autobombo, se agregó un segundo nombre, Eungenio (sic), que usa solo en ocasiones protocolares. En 2007, inventó Larenland, su propio país de un metro cuadrado, que se encuentra donde él esté, reino del que dice ser único habitante y soberano indiscutido. A través del tiempo, diseñó para su país una bandera celeste con estrellas blancas y plato volador de insignia española (recibió esa segunda nacionalidad en 2012), una moneda oficial (el dolaren), una gaseosa nacional (la Naranjoda), cepas vitivinícolas locales productoras del Atorrantés y del Cabaret Sabañón, un monumento representativo (el Obearisco, mezcla de Estatua de la Libertad, Obelisco y Torre de Pisa), un mapa de límites precisos (el Mar Mota y el Mar Avilloso rodean la isla de Larenland), una línea de fragancias, "Colonization", (es técnico químico como el Papa Francisco, suele recordar) y conformó un gabinete de ministros integrado por sus amigos coleccionistas y artistas plásticos.

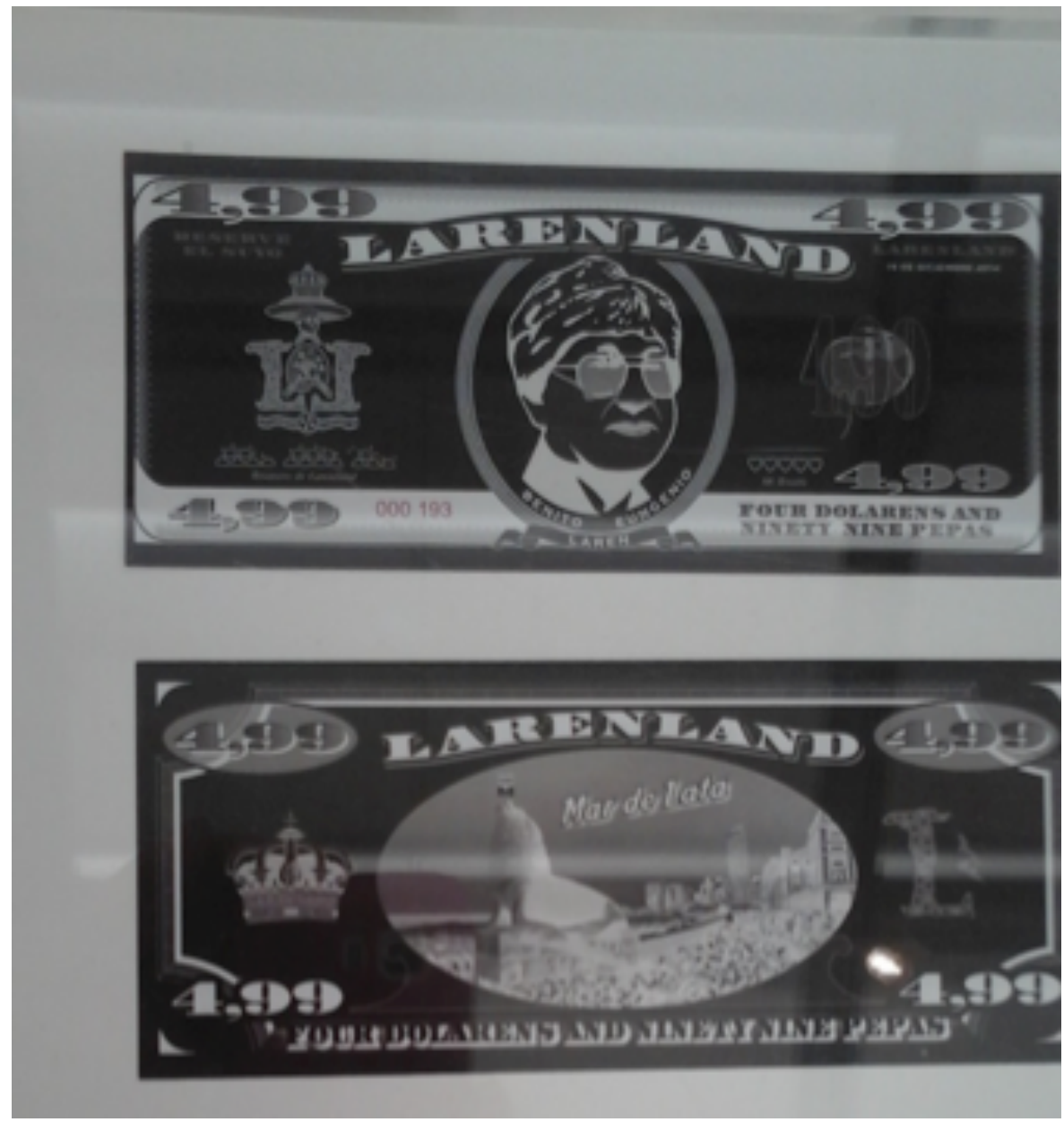

Dolaren $^{1}$
1. Las imágenes reproducidas son fotos tomadas por la autora de la exposición Fabularen, presentadas en el Museo Fortabat, en 2017 y de Benito Laren (2013). 
Para lograr el reconocimiento internacional de la soberanía de Larenland, el artista diseñó cincuenta modelos de estampillas. En la mayoría de ellas aparece él mismo encarnando diferentes personajes: el tanguero Carlos Burdel, próceres nacionales (San Martir y Manual de Ver Granos), símbolos navideños (Papá no es él), Príncipe de Gales junto a Lady Di o el Papa Rulo, Su Santidad el Papayaso, el Papa Nata, que forman parte de la serie vaticana, entre muchas otras. Con estos timbres postales hizo circular más de dos mil cartas que ya sellaron en diferentes países.

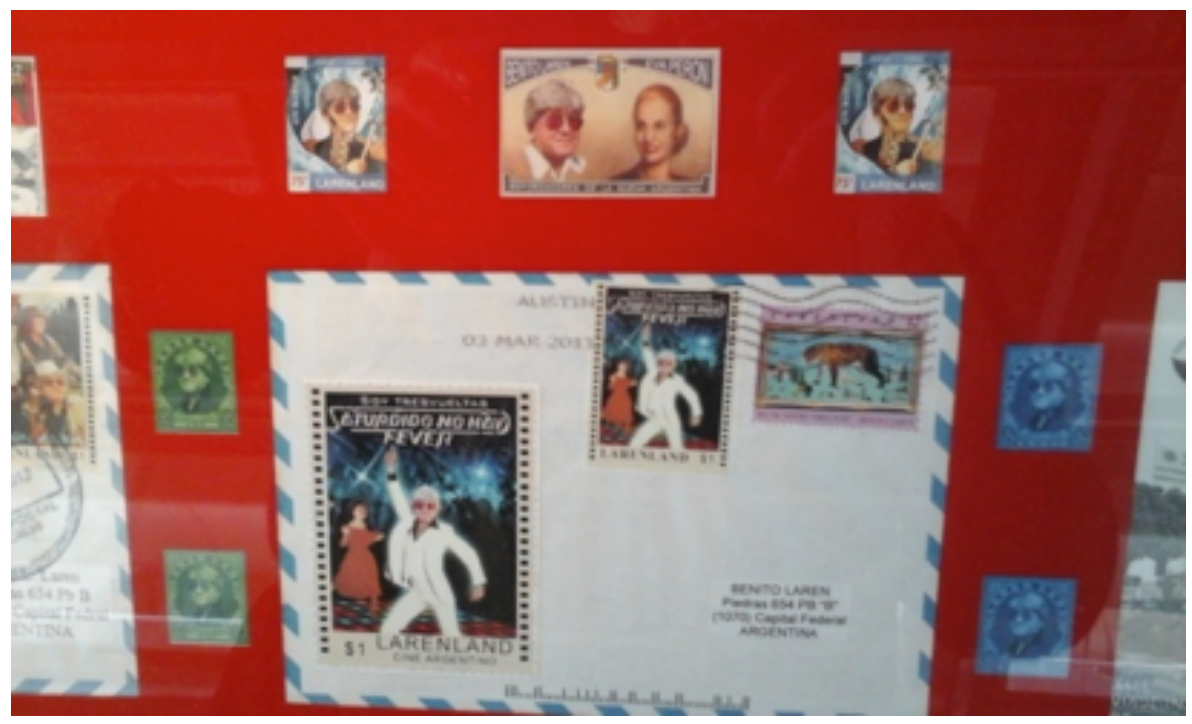

En su nueva casa del barrio de Caballito, creará la embajada de Larenland, una suerte de centro cultural, en una de cuyas salas instalará un trono (cfr. Soto, 2019) y, siguiendo el ejemplo de la orden del tornillo creada por otro Benito -Quinquela Martín-, entregará premios especiales a sus visitantes destacados.

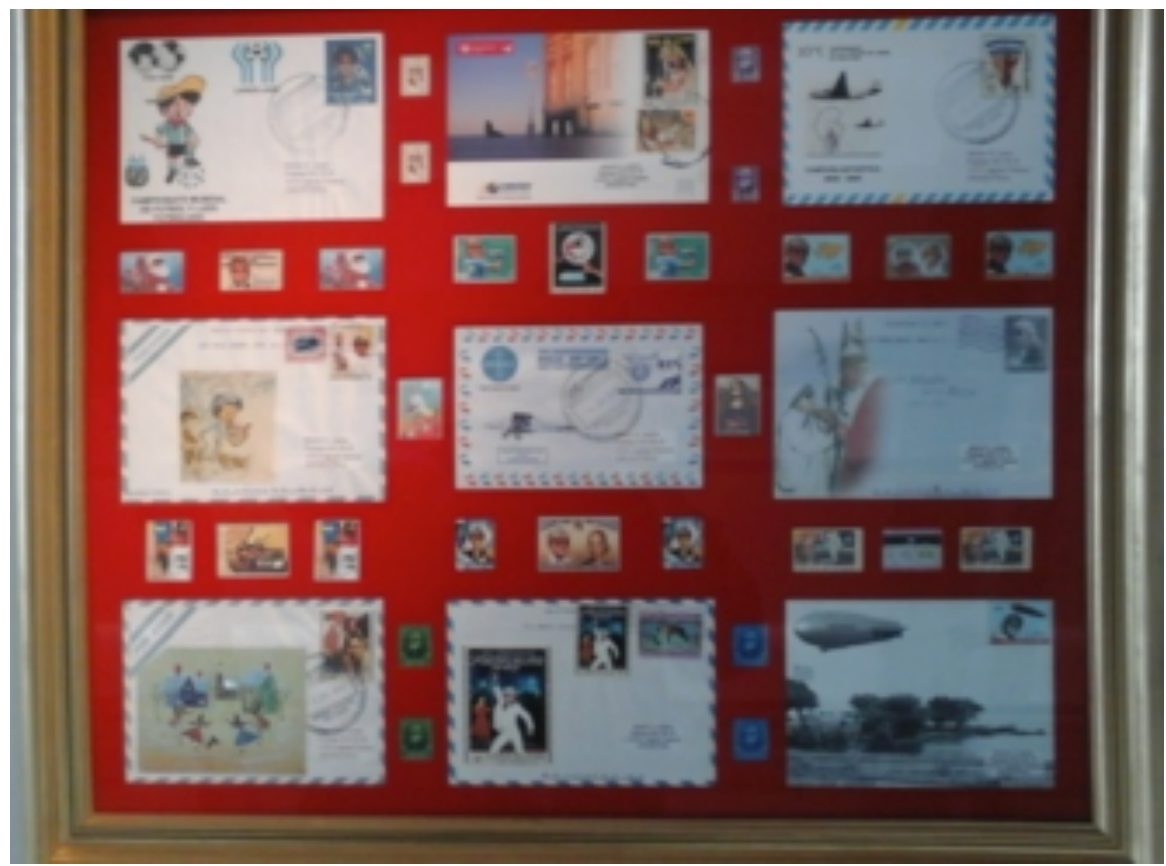

Con infaltables anteojos negros, que recuerdan a Marta Minujin, y con peluca, al modo de Andy Warhol o Federico Klemm, Laren suele aparecer públicamente vestido con 
un traje blanco con charreteras y entorchados, similar al de otro rey, Elvis Presley. Laren reforzó así la invención de una autoficción tan estrafalaria como su propia estética. Literatura, fotografía, escultura, collage, música, canto, baile, actuación televisiva, performance, instalaciones, videoarte y guión cinematográfico son las disciplinas de las que Laren se valió para crear un estilo personal de sesgo camp y humorístico, que denominó Pop OhArt y que se caracteriza por el empleo de materiales inusuales -vidrios esmaltados, espejos, monedas, hologramas, papeles metálicos, brillantina, resinas de fabricación propia, y de soportes también infrecuentes, como ruedas de bicicletas, latas de galletitas, matafuegos, ruletas de casino, celulares, puertas de autos y raquetas.

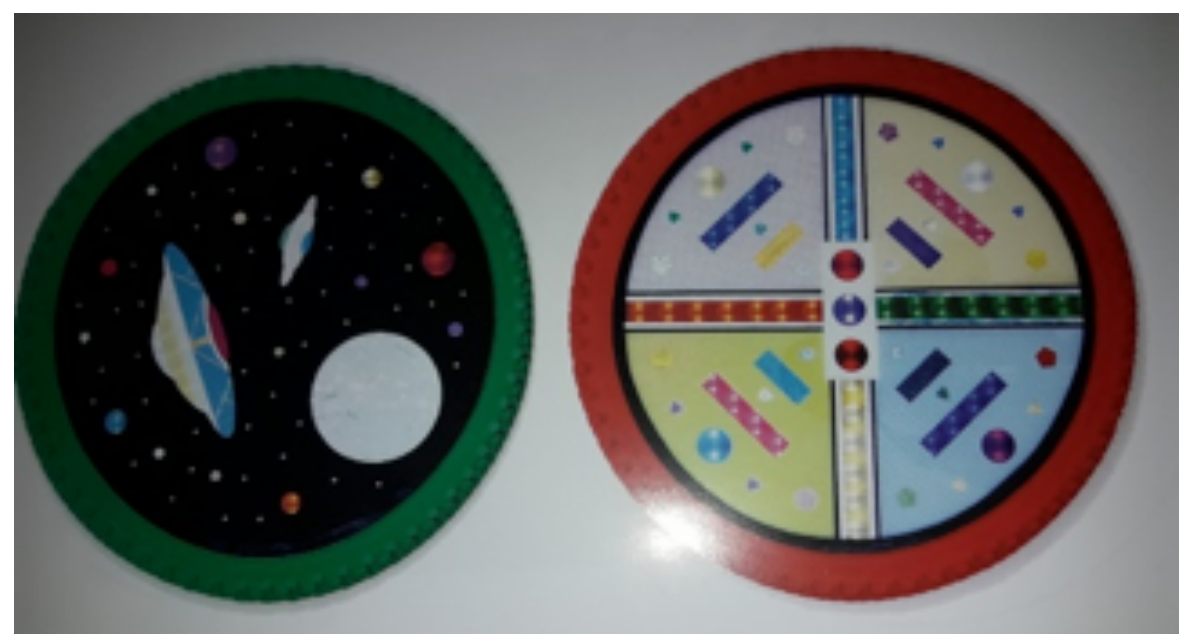

Imagen ruedas de bicicletas

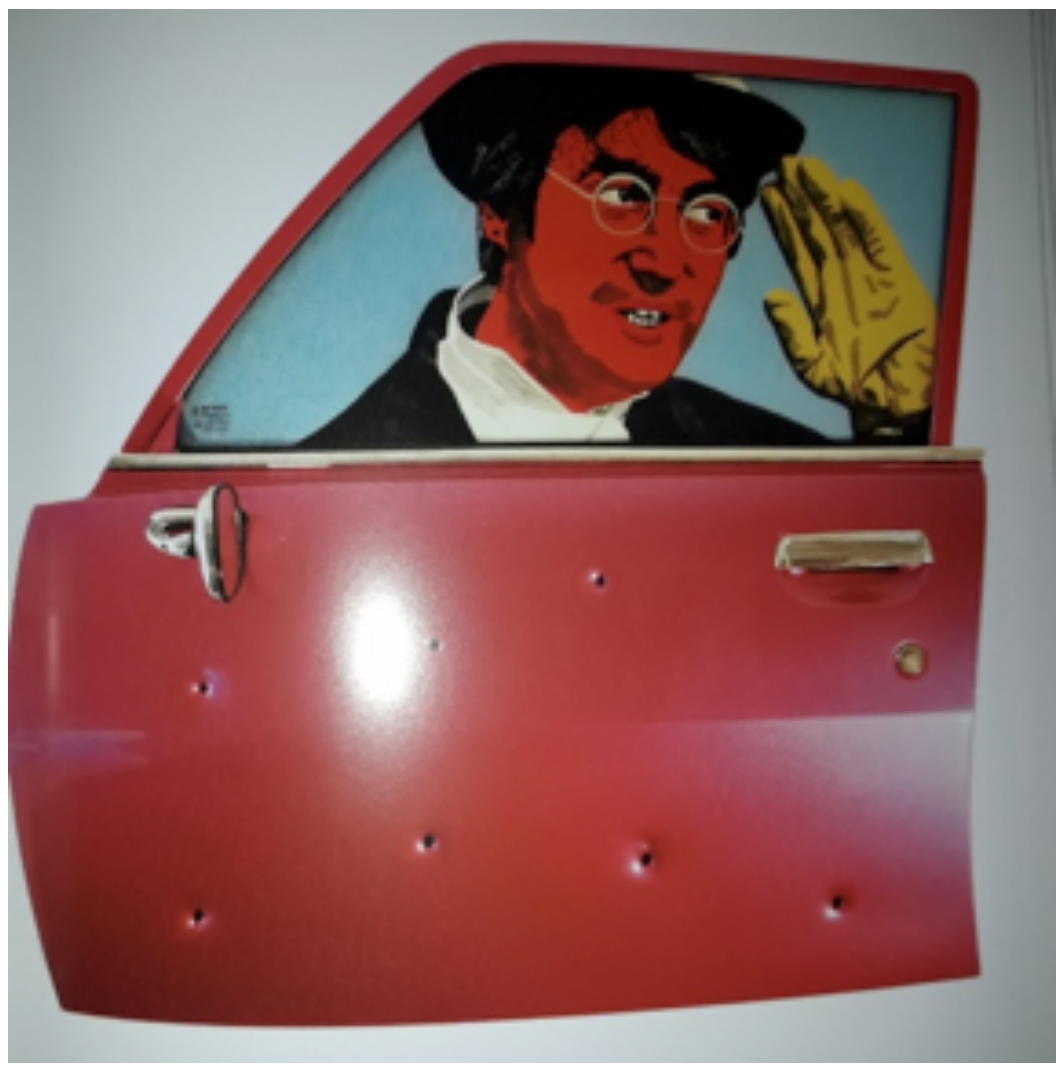

“La puerta Bony ta” (2003) 


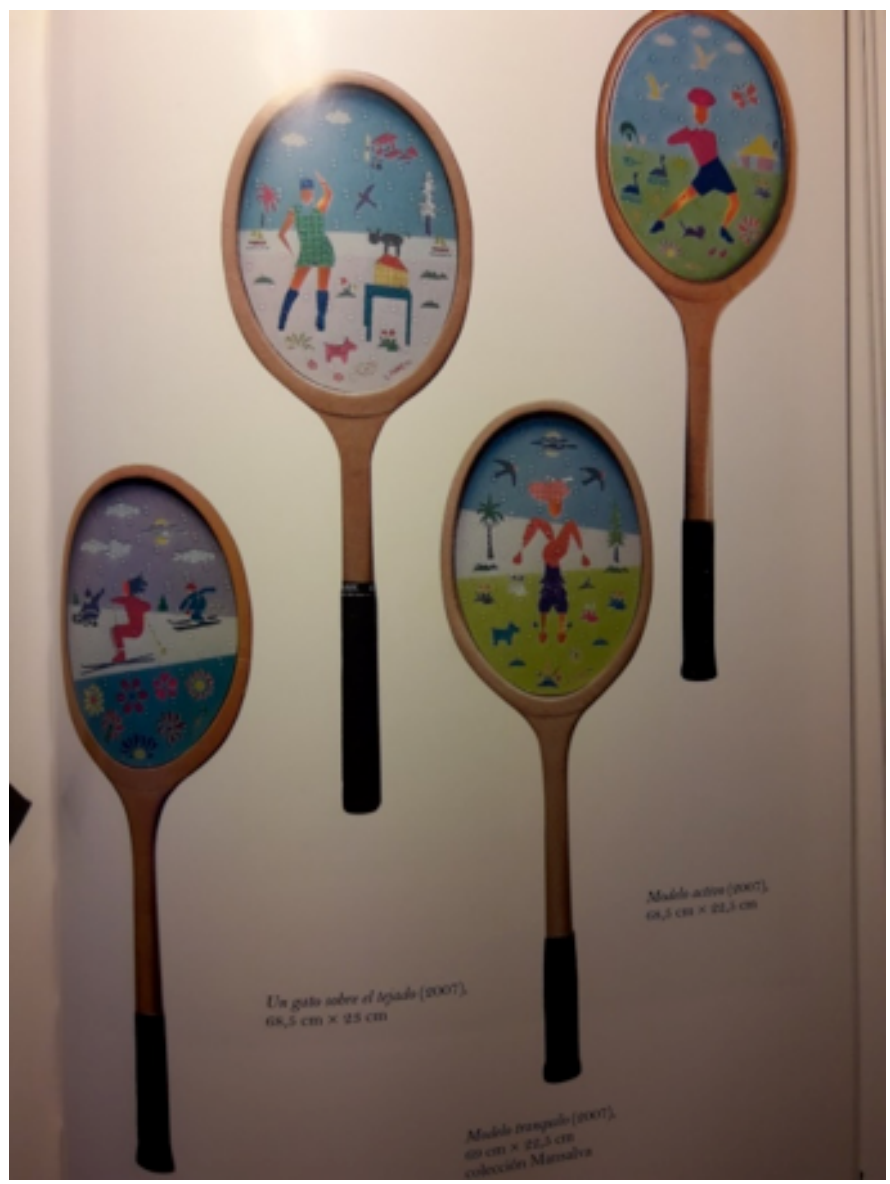

Raquetas

Asimismo, Laren creó una técnica original y exclusiva, la cuadrejización, que Natalia Pineau (s/f) explica así:

El término "cuadrejo" proviene de la combinación de las palabras "cuadro" y "espejo". Esta técnica consiste en pintar sobre una placa de vidrio que luego es invertida para adosarle por detrás una placa de espejo. De esta manera, el material pictórico queda apresado entre una y otra placa, generando una extraña sensación visual.

¿Cómo tomar en serio, entonces, a un artista cuyo rostro -conocido a medias, disimulado detrás de disfraces, anteojos y pelucas- vemos reproducido en la mayor parte de sus obras y cuyos datos biográficos, que oscilan entre la realidad y la más disparatada ficción, se construyen y reconstruyen en youtube, en sus performances e, inclusive, en los textos dedicados a su producción visual (Benito Laren, 2013)? ¿Cómo considerar artista a quien afirma que solo copia y calca imágenes, porque asegura no saber dibujar? ¿Cómo interpretar un corpus visual ecléctico que, jugando a veces con la desmesura y la miniaturización, se caracteriza por la duplicación, la parodia, la semejanza, la copia, la cita y la remasterización de obras de artistas célebres, procedimientos que el artista justifica irónicamente en términos casi sociales ("La gente no puede tener obra maestra porque son carísimas, entonces las copio, las remasterizo; las estoy readaptando. Saco de una y pongo de otra" [en Soto, 2019])? ¿Cómo valorizar -algo decisivo en el mundo del mercado de arte- a quien, considerándose artista, prioriza sin ambages, lo meramente lucrativo (" ¿Viste que hay distintos movimientos, el cubismo, el expresionismo? Mi movimiento es el oportunismo. Yo veo a quién le puedo vender un cuadro y después lo hago" [en Soto, 2019]). 
La perspectiva autoficcional parece aportar algunos indicios hermenéuticos a estos interrogantes. A pesar de sus orígenes medievales, cuando muchos autores se fingieron protagonistas de sus obras, la autoficción es el último de los géneros incorporados al campo de los estudios literarios: más precisamente, a partir de la publicación de Fils de Serge Doubrovsky en 1977, si bien el término autoficción empieza a circular recién veinte años más tarde, cuando el libro se reedita en formato bolsillo. Como señala acertadamente Claude Burgelin (2010), definir la autoficción se convirtió para los críticos en una especie de trabajo de Sísifo (cuando uno cree haber llegado, tiene que recomenzar desde otras perspectivas) o de condena tantálica (aunque creemos estar a punto de alcanzar una definición satisfactoria, jamás llegamos a aferrarla). Por ello, podríamos decir, en términos generales, que la autoficción es una modalidad de la escritura del yo basada habitualmente tanto en la identidad onomástica entre autor, narrador y protagonista, como en la declaración de ficcionalidad, realizada por medio de marcas paratextuales (por ejemplo, subtítulo que indica el género novela, dedicatorias, prólogos, aclaración sobre el carácter puramente casual de las semejanzas con personajes y hechos reales). En ciertos textos, se recurre tanto a la ausencia del nombre propio, a un pseudónimo o bien a una inicial; no obstante, en todos los casos, deben existir vinculaciones más o menos estrechas entre éstos y el verdadero nombre del autor. Asimismo, suele emplearse la heteronimia, entendida como multiplicación o diversificación del yo autor/narrador. Sin que se confunda con el relato en clave o con la novela en primera persona, la autoficción, que también puede escribirse en tercera persona, ficcionaliza la experiencia de vida, poniendo el acento en la invención de una personalidad. Por otra parte, mientras que la autobiografía no puede reducirse a la supuesta objetividad atribuida a los discursos referidos a lo real, a lo histórico, a lo clínico, a lo biográfico, la autoficción no puede ceñirse a la sinceridad u objetividad: integra la ficción y la confusión que proviene del inconsciente.

Podría conjeturarse que la clave de la particular y compleja autoficción de Laren se cifró en la ingenuidad del rebautismo recibido por parte de sus compañeros de escuela, primero, y, luego, en la propia elección de su apellido. Si bien son muchas las razones que llevan a los artistas a adoptar uno o varios heterónimos, ciertamente Laren es más fácil de recordar que el apellido real del artista, de origen polaco, de ardua pronunciación y complicada ortografía y, por esta razón, la facilidad del seudónimo favorece las estrategias comerciales vinculadas a la circulación de su obra. Asimismo, el carácter lúdico del seudónimo resulta un nexo clave entre lo esencial de su estética y la extravagante autoficción que Laren construye en sus declaraciones mediáticas, en los autorretratos presentes en libros dedicados a su obra (véase Benito Laren, 2013) y en los videos humorísticos circulantes en la web que refuerzan los anteriores, ya que, como bien señala Spear (2010), las informaciones en línea no solo constituyen un paratexto que condiciona la lectura del pacto autoficcional, al favorecer la creación de identidades múltiples, sino que plantean una suerte de puesta en escena de sí, una forma de autoperformatización.

En Laren, estética y autoficción se articulan y se resemantizan en una suerte de relación de mutua didascalidad. En efecto, escritura límite, punto de encuentro (y desencuentro) entre teatro y literatura, las didascalias constituyen el aspecto más complejo y ambiguo del texto dramático y, al mismo tiempo, uno de los más específicos y determinantes de su teatralidad. No se trata sólo del hecho, por otra parte demasiado obvio, de que las acotaciones sirvan para orientar al lector/receptor (en esta categoría se incluye a los teatristas como mediadores entre autor y espectadores) acerca de la manera de crear, estructurar, modalizar, focalizar e interpretar el texto. Las didascalias condensan la duplicidad (presencia-ausencia, realidad-ficción) que funda lo teatral. Son a la vez actos ilocutorios representativos, que apuntan a la creencia, a hacer coincidir la palabra con el mundo, a comprometer al locutor con la verdad de lo expresado, y actos ilocutorios directivos, los cuales, en este caso, más que ordenar, sugieren los modos de materializar la propuesta dramática y/o suplican -indirectamente- una cooperación interpretativa por parte del receptor (Laillou-Savona, 1985). Si bien no suelen incluir marcas textuales 
particularizadoras (es habitual el empleo de la forma impersonal se), las acotaciones están dirigidas a un interlocutor preciso; esto es, a un lector lo suficientemente competente como para ser capaz de construir, al menos virtualmente, el contexto ficcional a partir de las coordenadas -espaciales, temporales, ambientales, sociales y psicológicas de los personajes- provistas por el dramaturgo. Sin embargo, la operatividad de las didascalias no se limita exclusivamente al texto dramático, ya que, en numerosas producciones artísticas contemporáneas, suelen interactuar en paridad de condiciones con otros lenguajes no verbales en la producción de sentido. A la manera de este funcionamiento del discurso didascálico, textos verbales e imágenes visuales de Laren se interrelacionan, explicándose y complementándose entre sí y orientando al receptor a construir, al menos virtualmente, el contexto ficcional. Aún más, esta suerte de recíproca función didascálica planteada entre las obras visuales y los textos verbales, como así también entre obra visual y datos autoficcionales, se hace ostensible y se potencia en una dirección doble y complementaria. Por un lado, a través del humor verbal (basado sobre todo en la paronomasia y el calambur) presente en los títulos, que funcionan a modo de macrodidascalia (Galopentia: 1993). Nos referimos, por ejemplo, a referencias al artista que cita y homenajea ("Un poco más de Respetto Ruti"); quiños humorísticos como "¿Qué será esto...?” para nombrar la pintura que remite a unos de los enigmáticos Pan Trees de Xul Solar; "Yo con honda", un cuadro en el que el propio Laren aparece personificando a la Gioconda, con una honda en la mano, mientras que, en un doble nivel de referencialidad lingüística, juega con el nombre de la performer Yoko Ono), o bien a través del humor de los textos inscriptos en las propias obras, la mesodidascalias, ya sea en las antes mencionadas series filatélicas, en los posters de cinematográficos ("Laren da Rabia, dirigido por Bin Laren", "Yo se lo pague", "Boy en alza") o en muchas de sus pinturas.

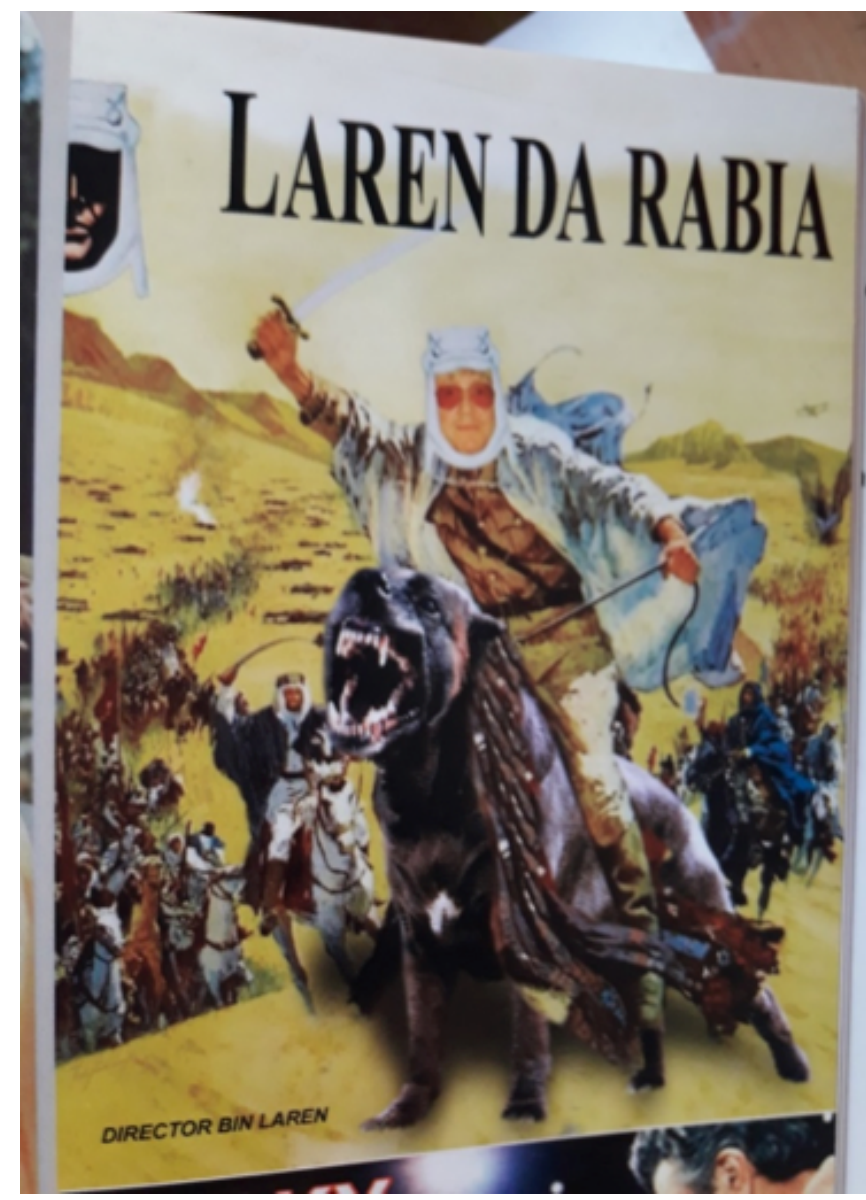

“Laren da Rabia, dirigido por Bin Laren”. 


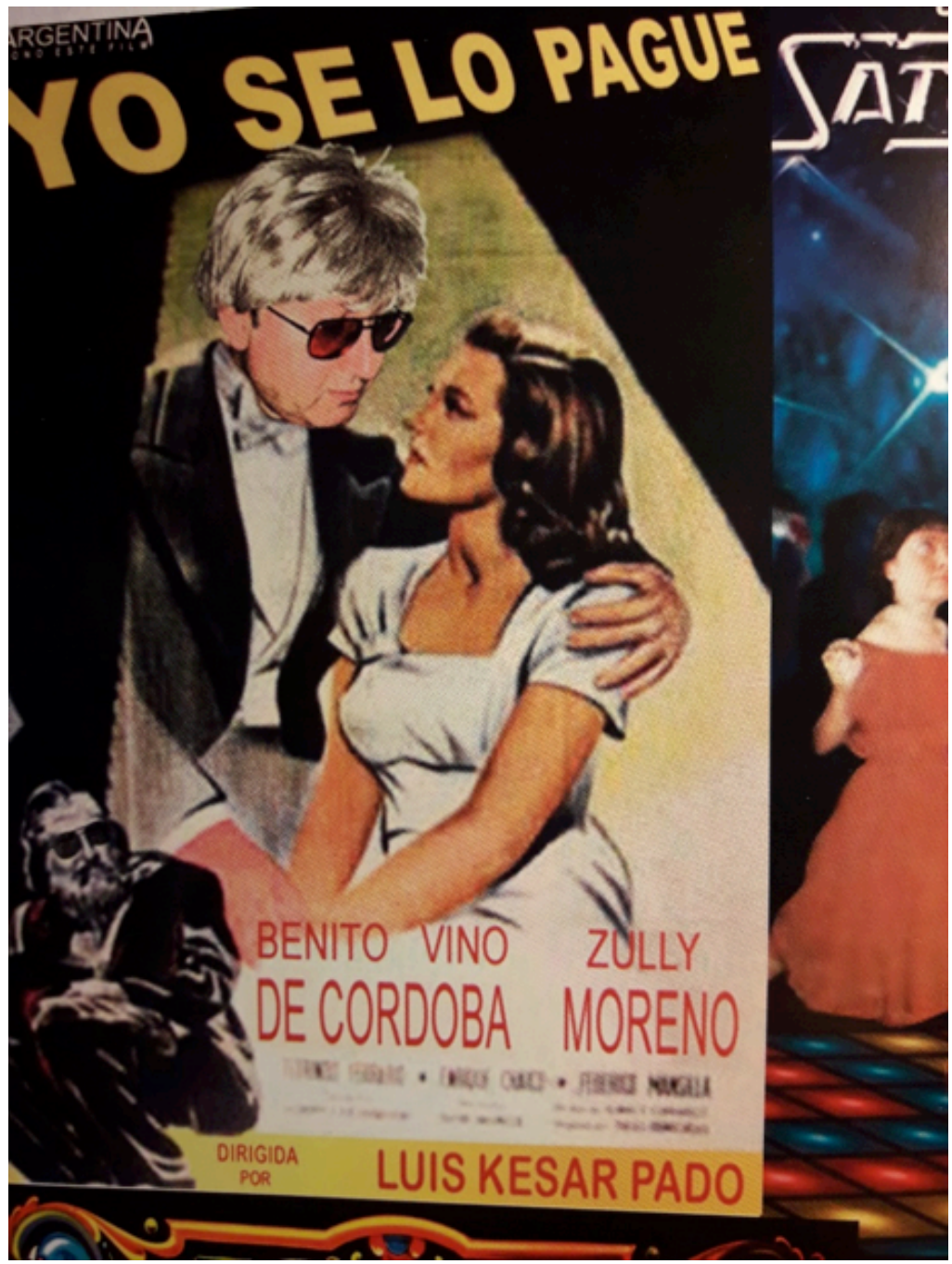

"Yo se lo pague"

Por otro lado, la función didascálica se verifica también a través de la intertextualidad visual de intencionalidad paródica, con respecto a la obra de artistas célebres como Van Gogh, Munch, Warhol, Lichtenstein, Picasso o nuestros más cercanos Cándido López, Xul Solar, Antonio Berni, León Ferrari, Guillermo Kuitca, entre muchos otros, algunos de cuyos personajes encarna con su propio rostro (tal es el caso de la madre costurera de "Primeros pasos" de Berni), así como también intertextualidad con otras disciplinas artísticas como la música popular, el cine o la televisión. 


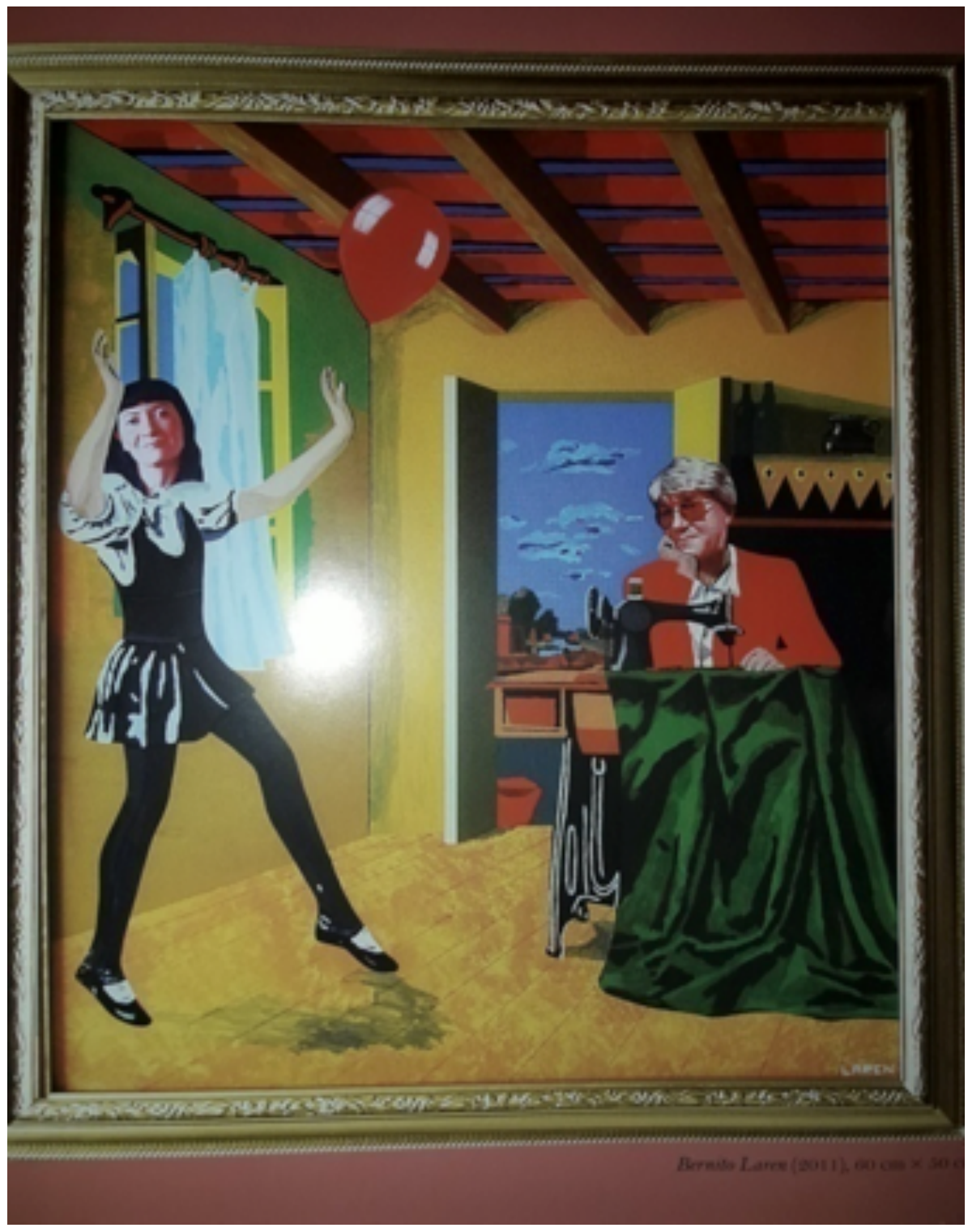

“Benito Laren” (2011)

Un buen ejemplo de esta mutua función didascálica reforzada por el humor verbal y la intertextualidad paródica es la pintura que reproduce el dormitorio de Arlés de Van Gogh, invertido especularmente según la técnica de cuadrejización antes comentada y con una estética que recuerda el estilo de Lichtenstein. Cómodamente recostada sobre la cama, la maja desnuda goyesca devuelve la mirada al observador, haciendo que el título del cuadro -“¿Qué hace usted aquí?"- sea la pregunta que especularmente se formulan entre sí personaje y espectador. 


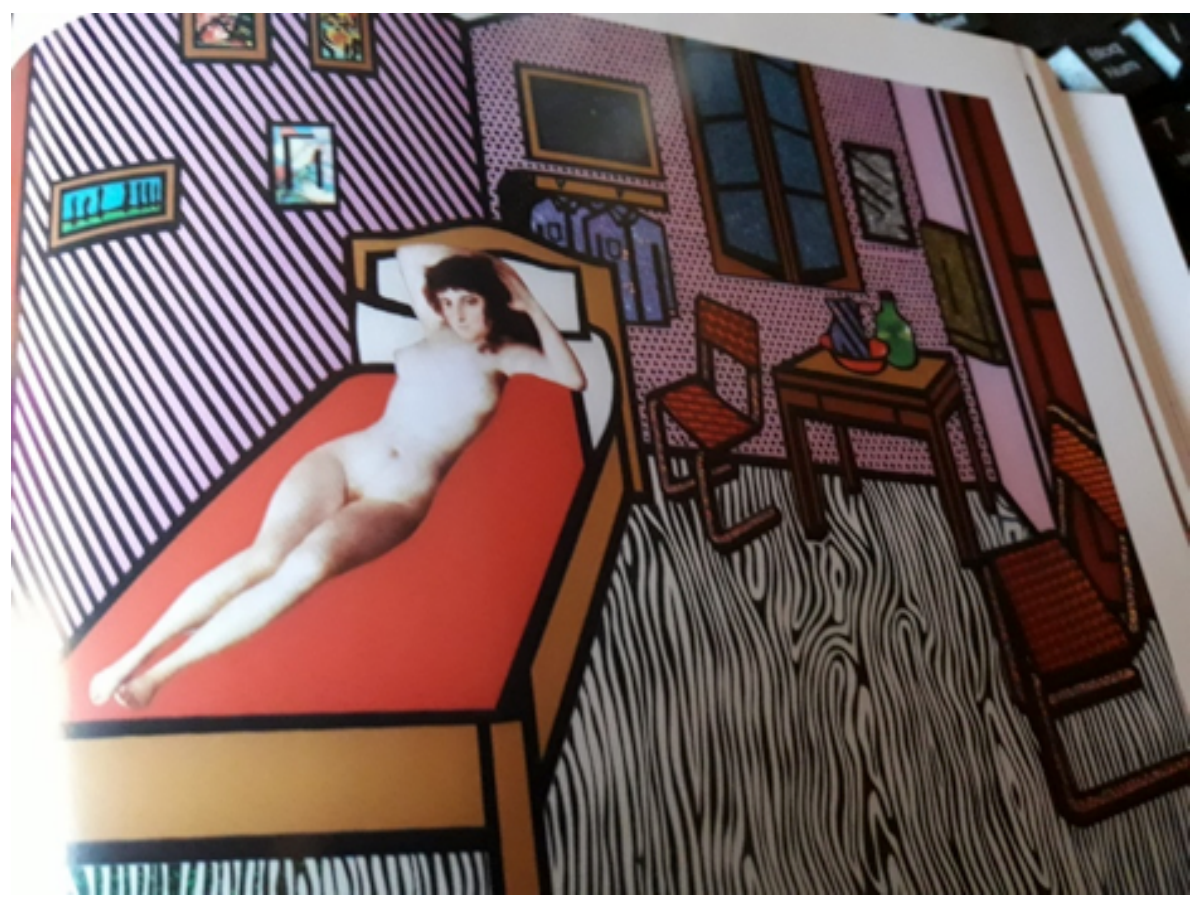

“¿Qué hace usted aquí?” (2012)

Al ser formulada por la maja de Goya, la pregunta evoca, a su vez, otra de más fácil respuesta: la célebre "¿Qué pretende Ud. de mí?" que Isabel Sarli pronunció en una escena de Yel demonio creó a los hombres (1960) de Armando Bo, pero que la vulgata atribuyó erróneamente a la película Carne (1968) del mismo director. Tal fue el convencimiento de los espectadores que, para no defraudarlos, dicha frase se agregó en una remasterización realizada varias décadas después de su estreno. Con esta profusión de citas y alusiones, Laren condensa, por tiro de elevación, una precisa autodefinición artística, al reenviar, por un lado, a la voluptuosidad de una star local y popular, ícono indiscutido de una filmografía hoy de culto, pero en su momento denostada por ir a contrapelo de la nouvelle vague y de todo lo consagrado en los Cahiers du Cinéma, filmografía considerada kitschig por su imaginería cargada de erotismo ingenuo, no exento de cierto humor bizarro, y, por otro lado, al referir a la manipulación entre original y copia para satisfacer en estas las fantasías de los receptores, pues, según las reglas del mercado, el cliente siempre tiene razón.

Las perspectivas hermenéuticas aquí consideradas -autoficción, discurso didascálico, copia y humor- se fundan en la ambigüedad, del mismo modo en que lo hacen la autoinvención y la obra visual de Laren. En efecto, la ambigüedad de la autoficción consiste fundamentalmente en el tipo de creencia propone. La autobiografía no puede reducirse a la supuesta objetividad atribuida a los discursos referidos a lo real, a lo histórico, a lo clínico, a lo biográfico; menos aún, la autoficción puede ceñirse a la sinceridad u objetividad: integra la ficción y la confusión que proviene del inconsciente. Por ello, la autobiografía pide ser creída, a partir del pacto entre emisor y receptor teorizado largamente por Lejeune (1973); la autoficción -siempre ambigua, siempre indecidible- pide, en cambio, ser y no ser creída al mismo tiempo, ya que se postula a la vez como falsa y seria, sin dar al lector las claves necesarias para diferenciar los terrenos de la realidad y la ficción (Darrieusecq, 1996). Por cierto, como observa Weigel (2011:29), mientras que el autor de un texto ficcional está enmascarado y el de una autobiografía teatral se presenta a rostro descubierto, el de una autoficción escénica se muestra con una media máscara de Narciso y de Proteo. Análogamente a esta ambigüedad de la autoficción, muchas de las informaciones que Laren hizo 
públicas en diferentes ocasiones y a través de distintos soportes son fácilmente corroborables; otras, indudablemente ficcionales; otras, en cambio, nos plantean serias dudas acerca de su veracidad.

A su vez, la ambigüedad del discurso didascálico se plasma en su capacidad de condensar la duplicidad paradojal (presencia-ausencia, realidad-ficción) que funda lo teatral, orientando así al receptor (sea lector o realizador escénico) acerca de la manera de crear, estructurar, modalizar, focalizar e interpretar el espectáculo resultante, a partir de las coordenadas que ofrece el dramaturgo, ya sean estas espaciales, temporales, ambientales, sociales o bien psicológicas y comportamentales vinculadas a los personajes. Siguiendo con la analogía, podríamos decir que ambos -vida/obra lareniana y discurso didascálico- plantean por separado y en su interrelación discusiones teóricas en torno de sus respectivas denominaciones; de su caracterización escritural; de sus múltiples intentos clasificatorios; de su calidad, extensión y eventual literaturización; de su autonomía o dependencia con respecto a otros textos; de su estatuto ficcional; de su capacidad diegética; de su relación con las distintas estéticas; de su predominio o desaparición a lo largo de la historia del arte, entre muchas otras cuestiones.

Desde fines de los años 30, con la legitimación de la reproducción técnica por medio de la fotografía, la fotocopiadora y el video, el concepto de copia, entendido en sentido amplio, conmocionó las estables bases del arte, al cuestionar la idea de obra única y aurática e impulsar al artista a la permanente investigación (Escribano Belmar, 2015), algo similar a la reflexión teórica en torno de las permanentes reproducciones que se dan en el teatro, ya sea en los ensayos (en francés, répétitions) o en la reiteración de las funciones, en tanto campos de incesante experimentación. La utilización lareniana de la copia, entendida en todos sus matices intertextuales, pero siempre diferente del plagio y de la falsificación, cumple una función lúdica similar al empleo del seudónimo. Ambos apelan, creemos, a segundas lecturas; esto es, operarían como "una metáfora del funcionamiento de la obra: miren bien, detrás de este seudónimo, está mi nombre; detrás de la ficción que les propongo, está la realidad de mis gustos, de mis rasgos de carácter y de mis deseos" (Montémont, 2010: 267).

La autoficción de Laren es también autorretrato, autorrepresentación, autoperformance, autoparodia y autopromoción: "Soy mi mejor público, mi club de fans y mi más minucioso hermeneuta") afirmó alguna vez (Benito Laren, 2013:27). Autoficción y obra visual, atravesadas por la misma comicidad se vuelven, en su interdependencia semántica, expresión de una sociedad posmoderna, hedonista, hiperindividualista y lúdica. Laren busca convertirse así en el modelo del personaje cómico contemporáneo que, como sostiene Lipovesky (1986), "ya no recurre a lo burlesco (...) su comicidad no proviene ni de la inadaptación ni de la subversión de las lógicas, proviene de la propia reflexión, de la hiperconciencia narcisista libidinal y corporal (144-145), haciendo reír "sin cesar en ningún momento de analizarse, disecando su propio ridículo, presentando a sí mismo y al espectador el espejo de su Yo devaluado. El Ego, la conciencia de uno mismo, es lo que se ha convertido en objeto de humor y ya no los vicios ajenos o las acciones descabelladas" (p.145).

Por otra parte, además de haber incursionado en numerosas e inusitadas actividades con las que pretendió lograr fama y riqueza, como tenis, filatelia, búsqueda sistemática de tesoros enterrados o elaboración de perfumes, aunque sin formación artística alguna, Laren supo inventarse como artista, no solo visual, sino artista en un sentido tan amplio que incluye la parodia de sí y, sobre todo, la de su exceso, es decir, la figura de la estrella construida por el star system hollywoodense. Como la star, Laren practica el paradójico incógnito de anteojos negros y vestuario llamativo (Morin, 1964); busca la belleza y la apariencia de eterna juventud (dijo alguna vez que comenzó a usar peluca en 2003, cuando quiso ser lindo y no pudo); juega, en la desmesura y el ridículo de 
sus performances, con lo cotidiano y lo fantástico, transformando al observador en un doble voyeur -de su obra y de la indecidible veracidad de sus datos biográficos- a través de la puesta en escena multisoporte de supuestos chismes e indiscreciones que con espíritu farandulesco mezclan lo público y lo privado.

¿Se propondrá Laren viralizar un mito individual? [...] Quizás se trata, en Benito Eungenio Laren, de la autofundación de una estética que ficciona lo sublime del pequeño dato ordinario de cada componente de la vida cotidiana, para convertirlo en lo extra-ordinario de una verdad inventada. (Ongaro Haelterman)

A modo de conclusión, podríamos decir que, al poner el acento en la figura del artista en tanto fundamento de su autoinvención y de su obra, Laren cuestiona el nuevo paradigma del artista que, como señala Deresiwicz (2015), ha dejado de ser aquel que profundiza en una única especialidad, para convertirse, por exigencia del mercado, en un emprendedor, en un constructor de múltiples identidades artísticas y, en el caso de Laren, también personales, capaz de superar no solo los límites de los lenguajes, las disciplinas y las técnicas, sino también de profundizar la desauratización del original como principio de valoración. El objetivo del nuevo modelo de artista -que, emblemáticamente, Laren parecen encarnar y en cierto denunciar- es ahora alcanzar una versatilidad tal que le permita la diversificación de su producción, que ya no está sujeta al gusto ni a la aprobación del mecenas, del crítico de arte o de los colegas artistas, como sucedió en distintos momentos de la historia del arte, sino exclusivamente a la pura satisfacción del cliente, que hoy, más que nunca, sigue teniendo razón. 


\section{Dibliografía}

» Burgelin, C. (2010). “Pour l'autofiction”, en en Autofiction(s). Colloque de Cerisy 2008, sous la direction de Claude Burgelin, Isabelle Grell et Roger.Yves-Roche, Presses Universitaires de Lyon; 5-21.

» Benito Laren (2013). Prefacio de Rafael Cippolini. Buenos Aires, Mansalva. Colección Popular de Arte Argentino.

» Darrieussecq, M. (1996). “L’autofiction, un genre pas sérieux”, Poétique, n. 107, sept.; 369-379.

»De Gracias, S. (s/f). “Copy Art y Electrografía. Cuando la copia es más bella que el original" Revista Malabia, no 49, Disponible en: http://www.revistamalabia. com/index.php/archivo/36-numero-49/48-copy-art-y-electrografia-cuando-lacopia-es-mas-bella-que-el-original.html

"Deresiwicz, W. (2015). "The Death of the Artist - and the Birth of the Creative Entrepreneur”. Disponible en https://www.theatlantic.com/magazine/archive/2015/01/the-death-of-the-artist-and-the-birth-of-the-creative-entrepreneur/383497/ [consultado el 16/02/18]

"Escribano Belmar, B. (2015). ¿Por qué llamarlo Copia, si es Original? El arte de la Copia Original o del Original Múltiple como estrategia creativa". Disponible en: http://original-vs-copy.interartive.org/2015/o7/copia-original-multiple/

» Galopentia, S. (1993). “Les didascalies de la source locutoire”, Poétique, n. 96, novembre.

"Laillou-Savona, J. (1985). "La didascalie comme acte de parole" Josette Féral, Jeannette Laillou-Savona, Edward A. Walker, (comp.). Théatralité, écriture, et mise en scène, Québec, Brèches Hurtubise $\mathrm{HmH}$.

»Lejeune, P. (1973). “Le pacte autobiographique”, Poétique, n. 14, avril; 137-162.

» Lipovesky, G. (1986). La era del vacío. Ensayos sobre el individualismo contemporáneo, Barcelona: Anagrama.

"Montémont, V. (2010). "Comment ne pas faire son autobiographie en 12+1 leçons: Jacques Roubaud”, en Autofiction(s). Colloque de Cerisy 2008, sous la direction de Claude Burgelin, Isabelle Grell et Roger.Yves-Roche, Presses Universitaires de Lyon; 257-279.

"Morien, E. (1964). Las estrellas de cine, Buenos Aires, EUDEBA.

»Ongaro Haelterman, C. (2017). Texto curatorial de la exposición Fabularen, presentada en la Colección de Arte Amalia Lacroze de Fortabat, Buenos Aires abril-julio. Disponible en https://www.coleccionfortabat.org.ar/gacetillas/prensa_fabularen_benito_laren_abril_2017_caalf.pdf

"Pineau, N. (s/f). “Comentario sobre Le moulin de la Galette" Disponible en https://www.bellasartes.gob.ar/coleccion/obra/11968 [consultado el 22/02/18]

» Soto, F. (2019, 22 de febrero). “Marte ataca. Entrevista a Benito Laren”, Página 12. Disponible en https://www.pagina12.com.ar/176039-marte-ataca

»Spear, Th. (2010). “Identités virtuelles”, en Autofiction(s). Colloque de Cerisy 2008, sous la direction de Claude Burgelin, Isabelle Grell et Roger.Yves-Roche, Presses Universitaires de Lyon; 441-460. 
»Weigel, Ph. (2011). “Autofictions au théÂtre: le demi-masque et la plume” en Florence Fix et Frédérique Touloire- Surlapierra (direc.), La autofiguration dans le théâtre contemporaine. Se dire sur la scène. Dijon: Ed. Universitairs de Dijon; $15-29$. 